\title{
Schistura fasciata, a new nemacheiline species (Cypriniformes: Balitoridae) from Manipur, India
}

\author{
Y. Lokeshwor ${ }^{1} \&$ W. Vishwanath ${ }^{2}$ \\ 1,2 Department of Life Sciences, Manipur University, Canchipur, Imphal, Manipur 795003, India \\ Email: lokeyum24@gmail.com¹, wvnath@gmail.com² (corresponding author)
}

Date of publication (online): 26 February 2011 Date of publication (print): 26 February 2011 ISSN 0974-7907 (online) | 0974-7893 (print)

Editor: K. Rema Devi

\section{Manuscript details:}

Ms \# 02454

Received 06 May 2010

Final received 10 December 2010

Finally accepted 31 January 2011

Citation: Lokeshwor, Y. \& W. Vishwanath (2011). Schistura fasciata, a new nemacheiline species (Cypriniformes: Balitoridae) from Manipur, India. Journal of Threatened Taxa 3(2): 1514-1519.

Copyright: @ Y Y. Lokeshwor \& W. Vishwanath 2011. Creative Commons Attribution 3.0 Unported License. JoTT allows unrestricted use of this article in any medium for non-profit purposes, reproduction and distribution by providing adequate credit to the authors and the source of publication.

Author Details: Y. LOKESHWAR is a Junior Research Fellow under a project funded by the Ministry of Environment \& Forests, New Delhi. He is working on the inventory of the nemacheiline loaches of northeastern India. $\mathrm{He}$ is undergoing $\mathrm{PhD}$ on a relevant topic in the Department of Life Sciences, Manipur University. W. VISHWANATH is a Professor in the Department of Life Sciences, Manipur University. His field of specialization is fish and fisheries. $\mathrm{He}$ is presently engaged in taxonomy and systematics of freshwater fishes of northeastern India.

Author Contribution: see end of this article.

Acknowledgements: We are grateful to the Ministry of Environment \& Forests, New Delhi (Project No. 14/11/2006-ERS/RE) for financial assistance and to J. Sylvester, student of Don Bosco College, Maram, Senapati District Manipur for helping in the collection of fishes.
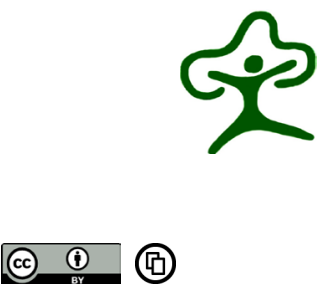

OPEN ACCESS | FREE DOWNLOAD
Abstract: A new nemacheiline fish, Schistura fasciata sp. nov. is described here from Barak River (Brahmaputra Drainage) of Manipur, India. The species is characterized by 11-13 dark brown transverse bars on the flank, moderately high adipose crest on dorsal and ventral side of caudal peduncle, three prominent dark spots at the base of dorsal fin, dorsal fin with $81 / 2$ branched rays and an incomplete lateral line.

Keywords: Barak River, Nemacheilinae, new fish.

\section{INTRODUCTION}

Fishes of the genus Schistura McClelland are small, hill stream fish with medially interrupted lower lip without forming two lateral triangular pads; moderately arched mouth, 2.0-3.5 times wider than long; usually a black bar (sometimes dissociated) on caudal fin base; dorsal fin with one or two black marks along its base (Kottelat 1990; Vishwanath \& Laishram 2001). Eight species of the genus Schistura have been described from two major drainages of Manipur, a hilly state in northeastern India, namely, $S$. manipurensis (Chaudhuri, 1912), S. kangjupkhulensis, S. prashadi, and $S$. sikmaiensis (Hora, 1921), S. tigrinum (Vishwanath \& Nebeshwar, 2005), S. reticulata (Vishwanath \& Nebeshwar, 2004), S. khugae (Vishwanath \& Shanta, 2004a,b), and S. minutus (Vishwanath \& Shantakumar 2005).

Collections from the Barak River (Brahmaputra Drainage), draining the western side of Maram Hill, Senapati District, Manipur included specimens of Schistura which do not fit into the hitherto described species of the genus, and is therefore described as a new species, Schistura fasciata.

\section{MATERIAL AND METHODS}

Fish were collected by electro-fishing technique using a DC battery. Colour in fresh state was noted before fixation and preservation in $10 \%$ formalin. Measurements were made point to point with dial calipers to the nearest $0.1 \mathrm{~mm}$ and expressed as percentages of standard length (SL). Subunits of head are expressed as proportions of the head length. Numbers in parentheses following meristic data indicate number of specimens examined with that count. Counts and measurements were made on the left side of specimens and followed Kottelat (1990). The specimens are deposited in the Manipur University Museum of Fishes (MUMF). 


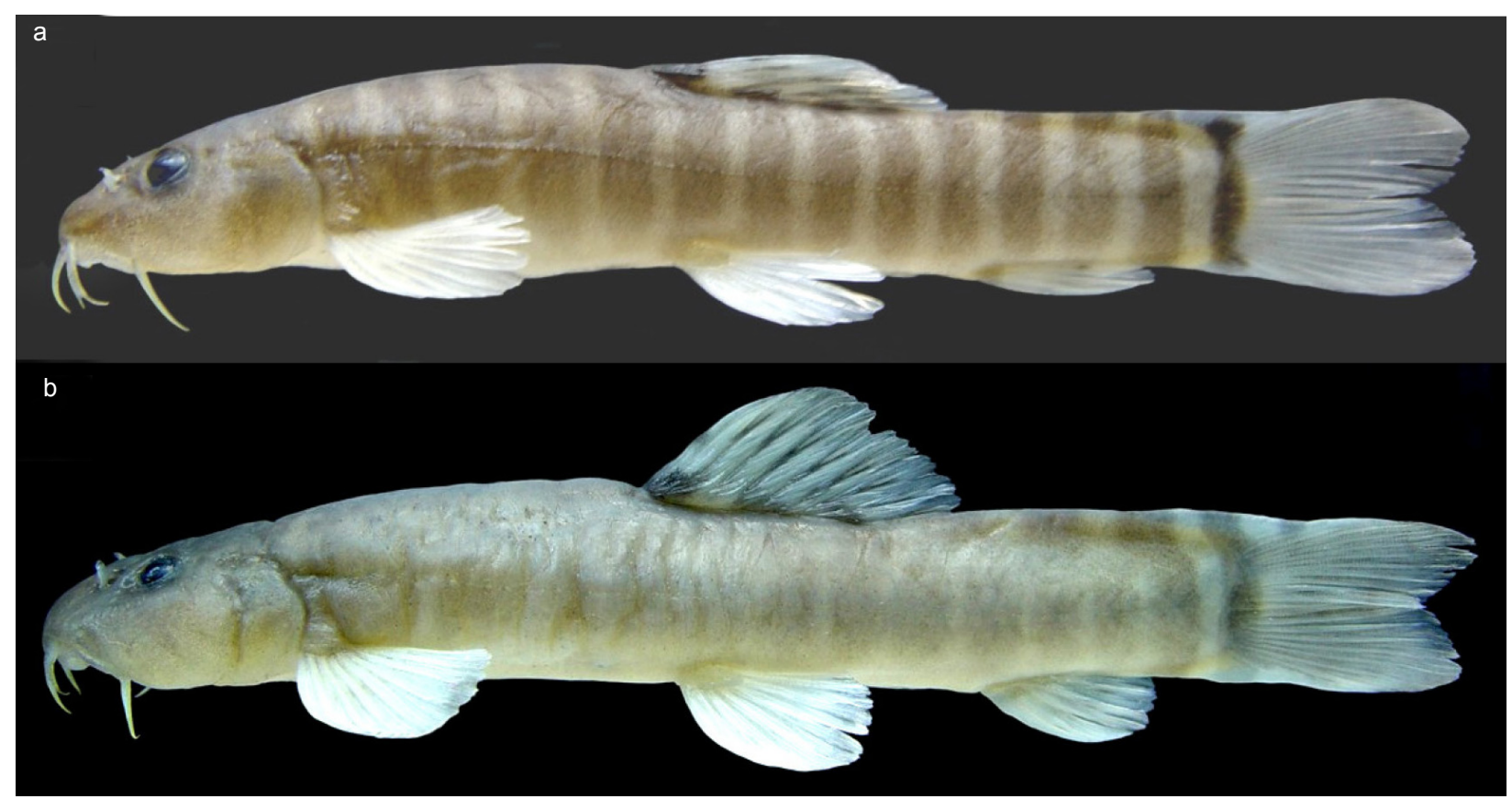

Image 1. Schistura fasciata sp. nov.

a - Side view of Holotype, female, MUMF 11010, 51.5mm SL; b - Paratype, male, MUMF 11020, 68.3mm SL

\section{Schistura fasciata sp. nov.} (Image 1 a \& b)

\section{Material examined}

Holotype: Female, 21.vi.2009, Barak River at western side of Maram Hill, Senapati District, Manipur (25023'24.66”'N \& 940'이.25”E), coll. Y. Lokeshwor, MUMF 11010, 51.5mm SL.

Paratypes: 18 females, 37.5-59.9 mm SL, MUMF 11001-11019; 2 males, 59.2-68.3 mm SL, MUMF 11020-11021. Same data as holotype.

\section{Diagnosis}

A species of Schistura with the combination of characters: 11-13 dark brown transverse bars against pale yellow background on the body, bars arranged regularly, often fused on mid-dorsal line, width of bar broader than the interspace width; moderately high adipose crest on dorsal and ventral sides of caudal peduncle; lateral line incomplete, reaching vertical to posterior end of anal fin base; three black spots on base of dorsal fin; head short (12.72-16.41 \% SL), dorsal fin with $8 \frac{1}{2}$ branched rays; processus dentiformes large.

\section{Description}

Morphometric data are shown in Table 1. Body small and moderately elongated. Anterior section of the body circular and slightly compressed posteriorly. Head short about 18.6-22.7 \%SL, slightly depressed with less inflated cheeks. Male has prominent inflated cheeks (Image 1b). Dorsal adipose crest moderately high extends from posterior extremity of dorsal fin base to caudal origin. Pectoral extends up to half the length of the distance between pectoral and pelvic fin origins. Auxiliary pelvic fin lobe is present; pelvic fin slightly behind the origin of dorsal fin, opposite to the first branched dorsal fin rays. Dorsal fin inserted half way between the origin of pectoral and anal fin. Caudal fin is emarginated.

D. $3 / 8 \frac{1}{2}$; A. $3 / 5^{1 / 2}$; C. $9+8$; P. 11 ; V. 8.

Body covered by embedded non-overlapping scales. Lateral line incomplete extends to vertical of the posterior end of anal fin base. Cephalic lateral line system with 10 supraorbital, 4+9 infraorbital, 10 preoperculo-mandibular and three supratemporal pores.

Nostril is situated nearer to anterior margin of eye, anterior nostril at the tip of a pointed flap like tube with a deeply notched anterior rim. Mouth moderately arched, upper lip straight with shallow median incision, lower lip with a deep median furrow (Image 2). Strong processus dentiformes present. Inner rostral barbel 
Table 1. Morphometric data of Schistura fasciata sp. nov.

\begin{tabular}{lcc}
\hline & $\begin{array}{c}\text { Holotype } \\
\text { MUMF } \\
\text { 11010 }\end{array}$ & $\begin{array}{c}\text { Paratypes } \\
\text { MUMF 11001-21 } \\
\text { (N=20) }\end{array}$ \\
\cline { 2 - 3 } & & Mean (Range) \pm SD \\
\hline Standard length (mm) & 51.5 & $49.3(37.5-68.3) \pm 7.4$ \\
\% SL & & \\
Body depth & 14.8 & $14.9(12.7-16.4) \pm 1.2$ \\
Head depth at supra-occipital & 11.9 & $11.4(10.2-12.3) \pm 0.6$ \\
Lateral head length & 25.0 & $23.4(21.2-25.4) \pm 1.1$ \\
Dorsal head length & 22.7 & $21.3(18.6-22.7) \pm 1.2$ \\
Head depth at eye & 10.1 & $9.7(8.9-10.8) \pm 0.4$ \\
Caudal peduncle length & 15.2 & $14.1(12.3-15.2) \pm 0.8$ \\
Caudal peduncle height & 11.7 & $12.4(11.1-13.5) \pm 0.6$ \\
Pre-dorsal length & 52.1 & $52.5(49.7-63.7) \pm 2.7$ \\
Pre-pelvic length & 52.0 & $53.2(51.1-54.9) \pm 1.0$ \\
Pre-anus length & 72.2 & $75.1(72.2-80.3) \pm 1.7$ \\
Pre-anal length & 77.6 & $78.9(76.5-80.9) \pm 1.1$ \\
Dorsal fin height & 15.4 & $13.8(12.1-15.6) \pm 1.1$ \\
Pelvic fin length & 17.1 & $15.6(13.6-17.7) \pm 1.0$ \\
Anal fin length & 16.1 & $14.2(12.7-16.1) \pm 0.9$ \\
Pectoral fin length & 19.4 & $17.3(14.7-19.4) \pm 1.2$ \\
Max. head width at cheek & 15.7 & $14.3(12.6-14.8) \pm 0.9$ \\
Head width (at nares) & 10.7 & $10.1(8.4-11.0) \pm 1.0$ \\
Body width at anal fin origin & 6.7 & $7.2(6.0-8.4) \pm 0.6$ \\
Body width at dorsal fin origin & 11.6 & $11.9(10.5-13.6) \pm 0.9$ \\
\% HL & & \\
Snout length & 34.1 & $36.7(31.2-45.2) \pm 4.1$ \\
Interorbital distance & & \\
Eye diameter & 27.5 & $28.6(25.06-34.83) \pm 2.5$ \\
Mouth gape width & 19.5 & $20.2(17.5-24.0) \pm 1.8$ \\
\hline & & \\
\hline
\end{tabular}

shorter than the outer one and reaches half way the distance from the anterior extremities of the body to anterior rim of nostril. The outer rostral barbel reaches the anterior margin of orbit. Maxillary barbel extends to the lower margin of orbit. Head longer than depth of the body, its width at nares is half of its lateral length. Eyes are moderate, dorsal in position and completely invisible from ventral side. Mouth gape is wide and about half of body depth. Intestine is with a small loop just behind stomach (Fig. 1).

Sexual dimorphism: Males are with swollen anterior body, triangular head and faintly coloured vertical bars especially visible from the middle of the dorsal fin to the base of the caudal fin whereas females

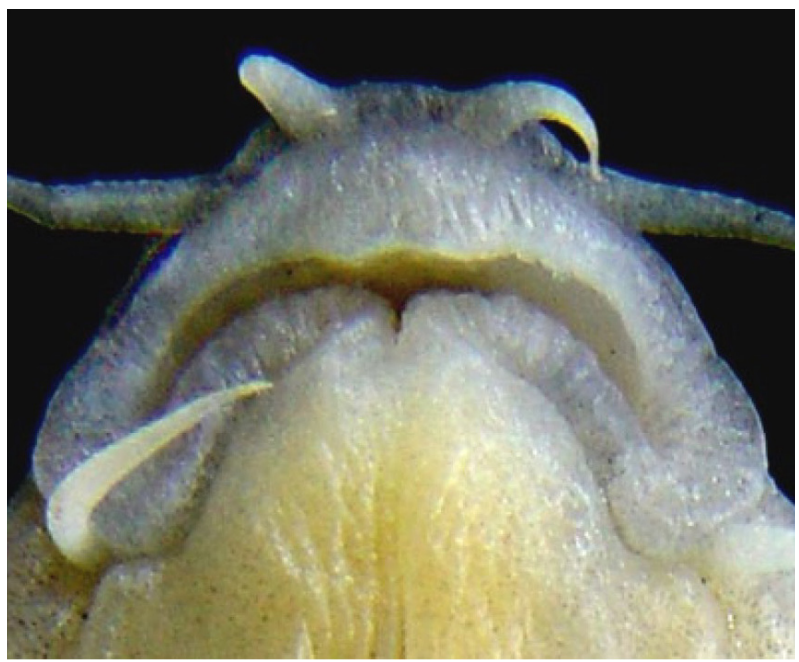

Image 2. Lips of Schistura fasciata sp. nov.

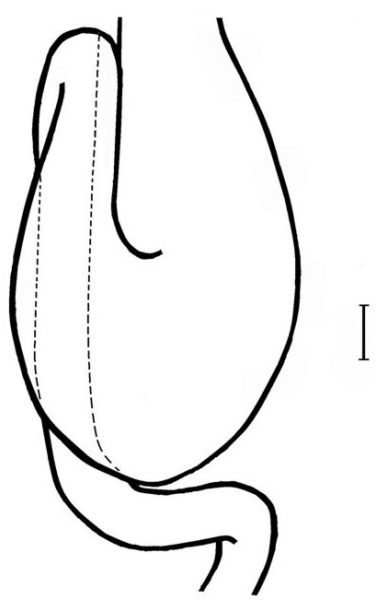

Figure 1. Intestinal loop of Schistura fasciata sp. nov. Scale bar $=1 \mathrm{~mm}$

have well distinct marked vertical bars. The dorsal surface of males is straight horizontally and with a well develop prominent dorsal adipose crest. The anterior dorsal profile of females are well arched and the adipose dorsal crest not prominent as in male.

Colouration: In live, body faintly golden to grey with 11 to 13 olivaceous dark brown vertical bars. Colour pattern and number of bars are more or less variable with a unique arrangement. 5-6 bars are on the pre-dorsal, 3 in dorsal and 4-5 bars on the postdorsal. Bars on the pre-dorsal are broader than the posterior ones. They are united mid-dorsally and their inter-bands are wider towards the posterior. All the rays of the dorsal, ventral, pectoral and anal fins are with a row of faintly black elongated marks. A complete dark caudal bar with forward and backward projections present on the base of caudal fin. Three 


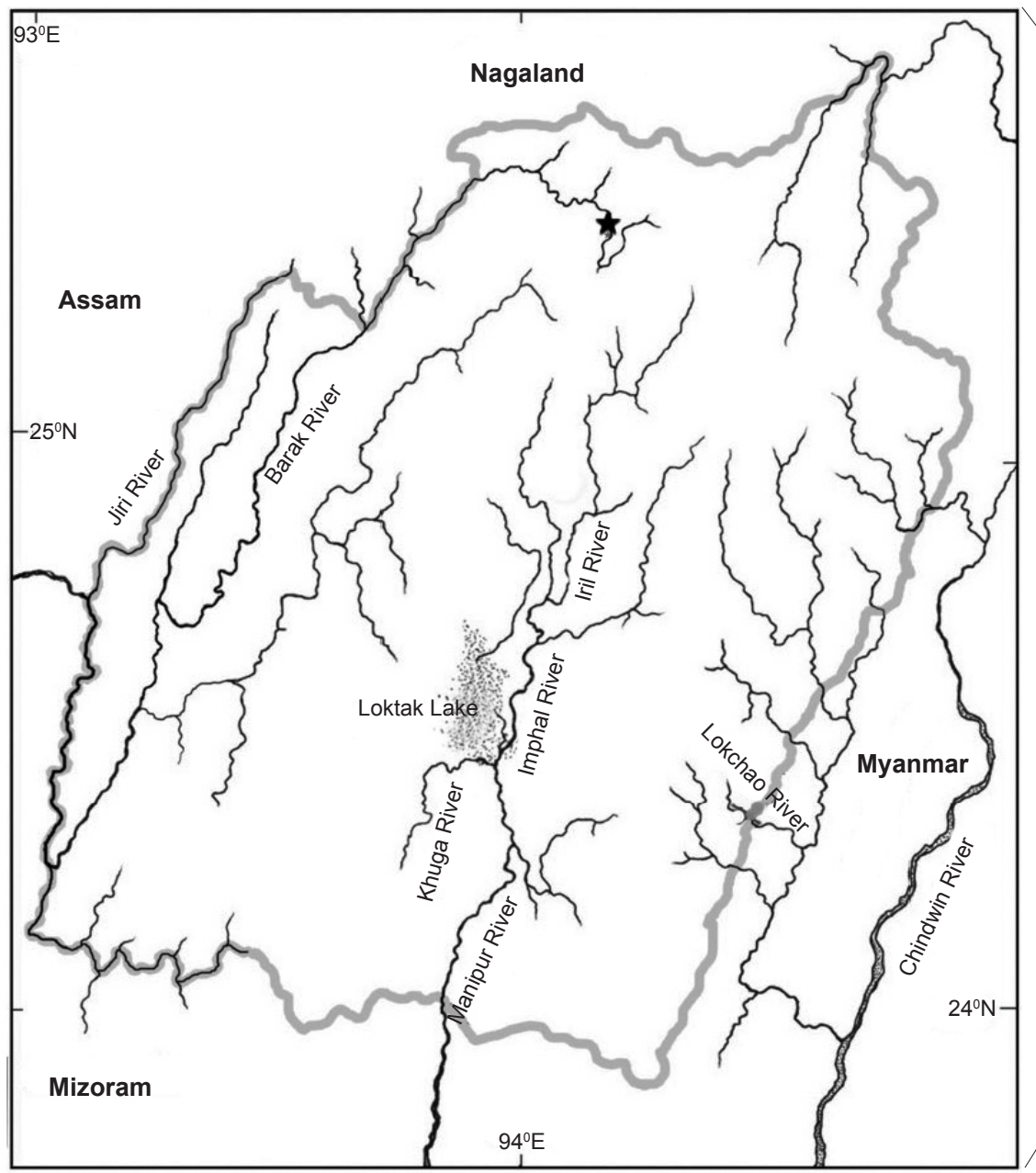

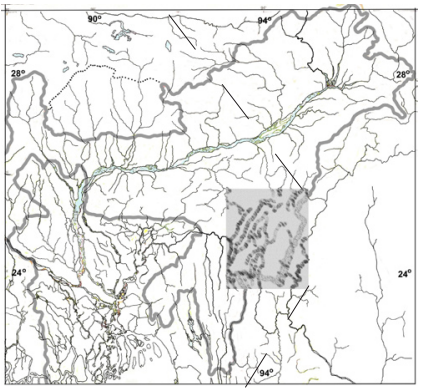

Figure 2. Map of Manipur showing type locality of Schistura fasciata sp. nov. prominent black spots on the base of the dorsal fin; respectively extending from simple rays to $1^{\text {st }}$ branched ray, from $3^{\text {rd }}$ to $5^{\text {th }}$ branched rays and from $7^{\text {th }}$ to last branched rays. Distal margin of fins golden. Head dark olivacious dorsally, becoming lighter on sides.

In $10 \%$ formalin, body becomes lighter with the loss of golden colouration in the interspace of vertical bars and on the distal margin of fins. The olivacious dark brown bars turn to light dark grey colouration.

Etymology: The fish has been named after its dark brown bars on body. Latin 'fasciata' = banded.

Distribution and Habitat: The species are known only from the type locality, Barak River at the western side of Maram Hill, Senapati District, Manipur (Fig. 2). The fish inhabits the pebbly bottom of large, swift flowing streams (Image 3).

\section{DISCUSSION}

Schistura fasciata sp. nov. is close to $S$. khugae, $S$. tigrinum and S. multifasciatus in colour pattern. But

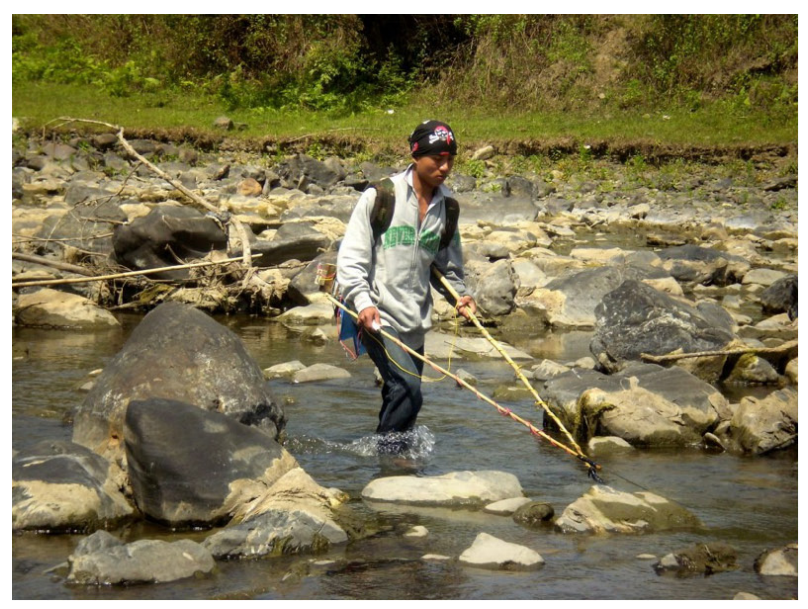

Image 3. Habitat of Schistura fasciata sp. nov. and electrofishing with locally designed equipment. 


\section{Key to species of the genus Schistura of Manipur}

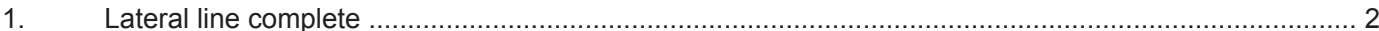

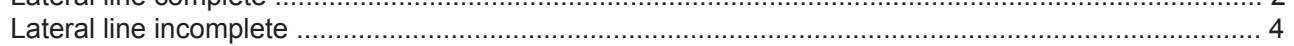

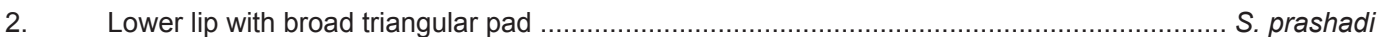

Lower lip without broad triangular pad .....................................................................................

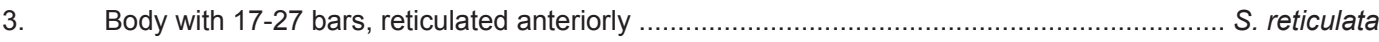

Body with 8-11 bars, not reticulated …………….................................................. S. chindwinica

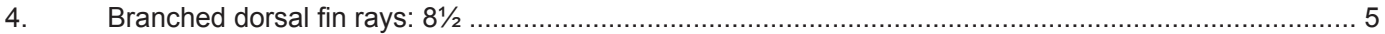

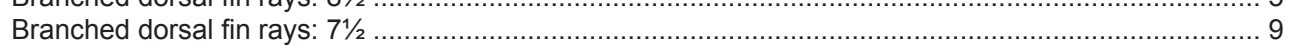

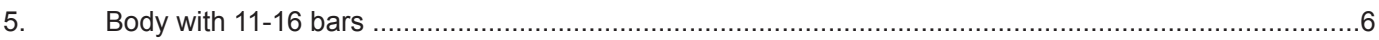

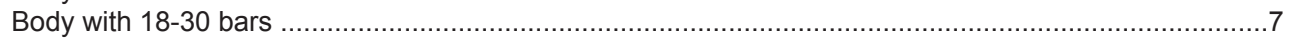

6. Caudal fin branched rays: 15 , bars on body: $10-11$, bars wide, interspace: $1 / 4$ of the bar width

S. nagaensis

Caudal fin with 17 branched rays, bars on body: 11-16, bars narrow, interspace: $2 / 3$ of the bar width....10

7. Caudal fin slightly emarginate, bars on body: 18 , anal fin with two simple rays ....................... S. minuta Caudal fin forked or deeply emarginate, bars on body: $18-30$, anal fin simple rays: 3 ....................... 8

8. Caudal fin deeply emarginate, bars on body: $18-30$, anal fin simple rays: 3 ........................ S. tigrinum Caudal fin forked, bars on body: 17-21, anal fin simple rays: 2 ...................................... sikmaiensis

9. Body with 7-11 regular bars, caudal fin branched rays: 15, no colour spot on fins .....S. kangjupkhulensis Body with 17-21 irregular bars, caudal fin branched rays: 15, dorsal and caudal fins with unevenly arranged spots .............................................................................................. manipurensis

10. Body with 15-16 bars, a black spot at dorsal fin base, anal fin simple ray: 1 ........................... khugae Body with 11-13 bars, three black spots at dorsal fin base, Anal fin simple rays three.

it can be distinguished from its congeners in having 11-13 colour bars (vs. 15-30), moderately long caudal peduncle (12.3-15.2) (vs. 12.4-20.0)\% of SL, three spots on the base of the dorsal fin (vs. 0-2), moderately long pectoral fin (14.7-19.4) (vs. 15.5-22.7)\% of SL, longer pre-anus length $72.2-80.3$ (vs. $70.3-75.0$ ) $\%$ of SL, moderately high dorsal fin 12.1-15.6 (vs. 11.7$18.0) \%$ of SL, moderate body depth $12.7-16.4$ (vs. $10.0-18.6$ ) $\%$ of SL, large eye $17.5-24.0$ (vs. 15.1$20.5) \%$ of HL.

Schistura fasciata sp. nov. can be distinguished from S. khugae Vishwanath \& Shanta (2004 a,b) of Khuga River (Chindwin Drainage), in having less number of bars on body (11-13 vs. 15-16), three black spots (vs. 2) on dorsal fin base, straight upper lip with median incision (vs. without median incision) and three unbranched simple anal fin rays (vs. 1) and in the extent of lateral line up to posterior end of anal fin (vs. vent or anal fin origin).

The new species can easily be distinguished from S. tigrinum Vishwanath \& Nebeshwar (2005) of Barak River in having less number of vertical body bar (1113 vs. 17-30), presence of black spots at the dorsal fin base ( 3 vs. nil) and the number of ventral fin rays ( 8 vs. 7).
Day (1878) described Nemacheilus multifasciatus (now Schistura) from Darjeeling and Assam. The type in ZSI was examined but found to be in a poor state of preservation and not suitable for comparison. Thus comparison was made based on data of Day (1978) and Menon (1987). Schistura fasciata sp. nov., differs from $S$. multifasciatus in having three simple dorsal fin rays (vs. 2), 81/2 branched dorsal fin rays (vs. $7^{1} \frac{1}{2}$ ), 11 pectoral fin rays (vs.12), three simple anal fin rays (vs. 2), 51/2 branched anal fin rays (vs. 5), eight ventral fin rays (vs. 9), 17 branched caudal fin rays (vs. 18) and incomplete lateral line (vs. complete lateral line). The vertical bars in $S$. fasciata sp. nov. are more or less equal in thickness and fewer in number (11-13) however in $S$. multifasciatus they are thinner and numerous to the anterior than the posterior and about (18-30).

\section{Comparative Materials}

Schistura tigrinum, holotype, $95.3 \mathrm{~mm}$ SL, MUMF 4105 ; 2005, paratypes, 2 specimens, 81.6-86.1 mm SL, Barak River at Khunphung, Tamei subdivison, Tamenglong District, Manipur, India, coll. Nebeshwar Sharma, MUMF 4106/7.

Schistura khugae, holotype, 67.0mm SL, MUMF 
5013; 08.iv.2000, 8 specimens, 58.0-96.5 mm SL, Khuga River, Chindwin Drainage, Churachandpur District, Manipur, India, coll. K. Shanta Devi, MUMF 5001-5008.

Schistura multifasciatus, holotype, Darjeeling, India, ZSI F2677/1 (poor state of preservation).

\section{REFERENCES}

Chaudhuri, B.L. (1912). Description of some new species of freshwater fishes from north India. Records of Indian Museum 7: 437-444.

Day, F. (1878). The Fishes of India; Being a Natural History of the Fishes Known to Inhabit the Seas and Fresh Waters of India, Burma, and Ceylon. Bernard Quaritch, London, 778pp+195pls.

Hora, S.L. (1921). Fish and fisheries of Manipur with some observations on those of Naga hills. Records of Indian Museum 22: 166-214.

Kottelat, M. (1990). Indochinese neamacheilines, A Revision of Nemacheiline loaches (Pisces: Cypriniformes) of Thailand, Burma, Laos, Cambodia and southern Vietnam. Verlag, Dr. Friedrich Pfiel, Munchen, 262pp.

Menon, A.G.K. (1987). The Fauna of India and the Adjacent Countries. Pisces, Vol. 4, Teleostei: Cobitoidea, Part I, Homalopteridae. Zoological Survey of India, Calcutta, 259pp+16pls.

Vishwanath, W. (2000). Fish Fauna of Manipur. Manipur Association of Science \& Society, 143pp.

Vishwanath, W. \& J. Laishram (2001). Fishes of the subfamily Nemacheiliane Regan (Cyprinidae: Balitoridae) from Manipur. Journal of the Bombay Natural History Society 98(2): 197-216.

Vishwanath, W. \& K. Nebeshwar (2004). Schistura reticulata, a new species of balitorid loach from Manipur, India with redescription of S. chindwinica. Ichthyological Exploration of Freshwaters 15(4): 323-330.

Vishwanath, W. \& K. Nebeshwar (2005). A new nemacheiline fish of the genus Schistura McClelland (Cypriniformes: Balitoridae) from Manipur, India. Journal of the Bombay Natural History Society 102(1): 79-82.

Vishwanath, W. \& K. Shanta (2004a). A new nemacheiline fish of the genus Schistura McClelland (Cypriniformes: Balitoridae) from Manipur, India. Journal of the Bombay Natural History Society 101(1): 138-140.

Vishwanath, W. \& K. Shanta (2004b). fish of the genus Schistura khugae a new replacement name for S. macrocephalus Vishwanath \& Shanta 2004 (Teleostei: Balitoridae). Ichthyological Exploration of Freshwaters 15(4): 330.

Vishwanath, W. \& M. Shantakumar (2005). A new nemacheiline fish of the genus Schistura McClelland (Cypriniformes: Balitoridae) from Manipur, India. Journal of the Bombay Natural History Society 102(2): 210-213.
Author Contribution: The study: YL survey, collection, morphometric and anatomic study of nemacheiline fishes of northeastern India and their phylogenetics; WV supervision of taxonomy and phylogeny of freshwater fishes of northeastern India. Current paper: YL detailed examination of the nemacheiline fishes of the Barak and its tributaries in Manipur and comparison with specimens in ZSI, Kolkata and in MUMF. WV supervision in establishing new species and discuss taxonomic status. 